\title{
Technical and Economic Analysis of Ship Launching with Slipway and Airbag KM. Sabuk Nusantara 72 in PT. Janata Marina Indah Shipyard Semarang
}

\author{
Sunarso Sugeng $^{1 *}$, Mohammad Ridwan ${ }^{1}$, Suharto $^{2}$, Samuel Febriary Khristyson ${ }^{3}$ \\ ${ }^{1}$ STr Programs Marine Engineering and Construction Technology, Department of Industrial Technology, Vocational \\ School, Diponegoro University, \\ Jl. Prof. Soedarto, SH, Kampus Undip Tembalang, Semarang, Indonesia 50275 \\ ${ }^{2}$ D3 Programs Ship Design and Construction Technology, Department of Industrial Technology, Vocational School, \\ Diponegoro University \\ Jl. Prof. Soedarto, SH, Kampus Undip Tembalang, Semarang, Indonesia 50275 \\ ${ }^{3}$ Department of Mechanical Engineering Faculty of Engineering, Diponegoro University \\ Jl. Prof. Soedarto, SH, Kampus Undip Tembalang, Semarang, Indonesia 50275
}

\begin{abstract}
In a ship, planning can not be separated from the planning of the ship launching process. A ship can perfectly glide if it has high enough planning time and costs. The launch process itself is divided into several ways. The choice of this method needs to be considered because it relates to the budget and preparations made. The method used is the calculation according to the numerical approach assisted by computational software. The first calculation is planned with the slipway launch, and then the next one is planned with the airbags that have been implemented previously. This study aims to provide analysis results as a consideration in implementing the slipway and airbag ship launching method on KM Sabuk Nusantara 72 measuring 2000 DWT. In steps 5 to 6, both the slipway and the airbags experience a stern lift condition with a value ( $y$ Vd) of 1396.97 tons. Based on the economic analysis of people's hours using airbags, there is a decrease in working hours by $44 \%$ compared to the launch using a slipway. This also happened to work productivity, where it was $84 \%$ more time effective. When viewed from an investment point of view, slipways are more economical than an airbag. The difference is $43 \%$ more economical using slipways. Both types of a launch can be applied by looking at the economic side and the ability of each shipyard in carrying out the launching process and seeing the main size of the ship to be launched.
\end{abstract}

Keywords: technical and economic analysis; ship launching; slipway; airbag; KM. Sabuk Nusantara 72

\section{Introduction}

In a ship, planning can not be separated from the planning of the ship launching process. A ship can perfectly glide if it has high enough planning time and costs (Ye, 1994). The launch process itself is divided into several ways. This method's choice needs to be considered because it is related to the budget and the preparations made. In general, there are several systems for ship launching (Fitriadhy \& Malek, 2017). Among them is the launching system is the end launching system. This system is a method of launching with the stern of the ship touching the surface of the water first. The consideration in launching with this method is the buoyancy and drag force, which

\footnotetext{
${ }^{*}$ Corresponding author

E-mail: sunarso.sugeng@gmail.com
}

allows greater than the bow. The ship launching process requires a substantial investment to plan the launch area (Fitriadhy \& Malek, 2017; Irawanto et al., 2019). As with the slipway system, a relatively expensive initial investment will be required to construct a skate structure with the track (Xiao et al., 2020). From this phenomenon, innovative technology is considered more practical. It has high economic value for a more flexible, safe, and reliable ship launching with no embedded assets, minimum maintenance, namely by using the airbag launching method, see Figure 1.

Previous research has shown that there have not been many investigations on slipway and airbag launching methods comparison. There are still a few references on both methods comparison (Fitriadhy \& Malek, 2017; Irawanto et al., 2019). In previous research, there are actual conditions in the field. However, it is challenging to predict 


\section{TEKNIK, 41 (3), 2020, 226}

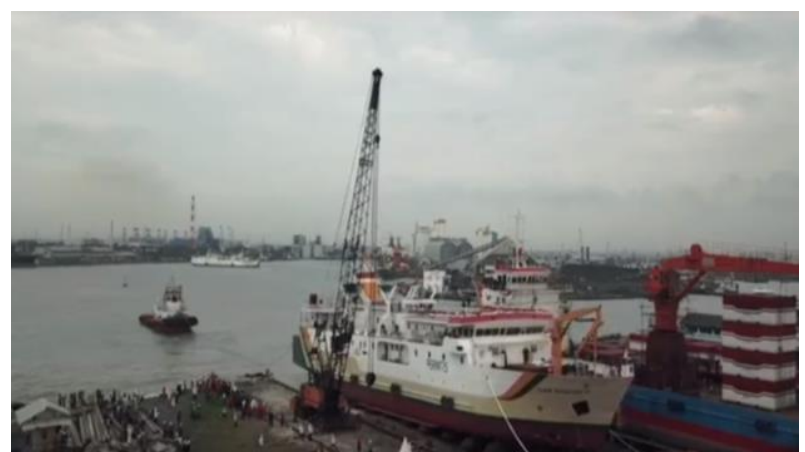

Figure 1. Ship launching with airbags

ship behavior when launched using airbags, critical conditions that occur at launch need to be analyzed to determine the standard flow of safety criteria in the ship launching method (Song et al., 2020).

In his research entitled "A hierarchical updating method for finite element model of airbag buffer system under landing impact", Huan He claimed the advantage of airbags use compared to slipways. He stated that there is about a $41 \%$ man-hours reduction. On the other side, investment costs are $37 \%$ lower than the slipway. Based on this data, it can be seen that the analysis of man-hours results in a $69 \%$ increase in productivity in the use of airbags for docking and undocking activities (He et al., 2015). However, according to Mann's research entitled "The KwaZuluNatal Boat Launch Site Monitoring System: A novel approach for improved management of small vessels in the coastal zone," ship launching using airbags has a potential risk of ship launch failure (Mann et al., 2015). There is a form of failure that occurs, such as an airbag erupting, resulting in the ship's overturning in the launching process. To reduce the launch failure risk, analysis is necessary for the form of technical and economic studies (Fitriadhy \& Malek, 2017; Irawanto et al., 2019). The need for a more in-depth analysis to support the success of the launching process and ship safety related to the success in the launching process and ship safety (Yamagami et al., 2006). The replacement of the skate construction that is fixed (fixed) into the airbag, which has a rotational/rolling movement, gives a dynamic effect that needs to be controlled (Senjanović et al., 2020). So that in its application in the field, there is a standard that can be used and is not based on experimental experience (Thomas et al., 2009). Basically, the ship to be launched has a cost that is quite expensive, so the launching process based on experimental experience needs to be minimized. What is of concern in the launching process is the ship's radio to be launched where the ratio of length to width is small, the conditions of the launch pad and water conditions are less than ideal (Ianagui \& Tannuri, 2015; Thomas et $a l ., 2009)$. The previous research, entitled "A recovery system for the key components of the first stage of a heavy launch vehicle," by Casper Dek, presents a comparative calculation of the launch diagram between conventional and airbag systems. The analysis results show that the float-off time is faster between the airbag system than conventional launches (Dek et al., 2020). Besides, a study entitled "experimental study of ship launching using airbags" by Irwanto compares launch calculations with DGPS measurements and video recording results. The analysis results show that the value is quite significant, especially in the projection of the position of the stopping of the ship due to uncertainties related to water resistance (Irawanto et al., 2019). Compared to the graving dock launching method, this method has the advantage of lower initial investment costs. However, in terms of the ship's safety and comfort, the launching process is safer using a graving dock.

On the other hand, the shipyard location also represents the capacity and capability of the shipyard in planning the type of launch that can be applied. The mechanical launch method, namely by using a crane or syncrolift dock, requires a large area and calm and comfortable waters. Meanwhile, the floating dock type requires a floating media in the form of a floating pontoon device of a certain size with a capacity capable of providing a greater carrying capacity than the DWT of the ship to be launched. The slipway and airbag launching method is still the main means used in many shipyards in Indonesia, apart from the contour of the shipyard layout and from an economic point of view.

The method comparison of this research is technical and economic analysis. This research's problem limitation is the waters, which are assumed to be at the highest tide of the month. The economic analysis considered is the launch implementation cost. However, the resistance of waves from seawater or the vibrations that arise in the ship launching process, calculations, and illustrations of the launch using the device computer software was not taken into account. The purpose of this study is to provide analysis results as a consideration in implementing the slipway and airbag ship launching method on KM. Sabuk Nusantara 722000 DWT.

\section{Materials and Methods}

In this study, the ship used was KM. Sabuk Nusantara 72 with the main sizes, as can be seen in table 1. A model is then made using a computer device (Computer-Aided Design) and depicted in a step condition of the launch period to make it easier to measure calculations. 


\section{TEKNIK, 41 (3), 2020, 227}

Table 1. Main Size of the Ship

\begin{tabular}{lcc}
\multicolumn{1}{c}{ Description } & Score & Unit \\
\hline $\begin{array}{l}\text { LOA (Length of Over All) } \\
\text { LBP (Length between }\end{array}$ & 68.5 & meter \\
Perpendicular) & 63.00 & meter \\
B (Bearth) & 14.00 & meter \\
H (Hight) & 6.20 & meter \\
T (Draught) & 3.50 & meter \\
DWT & 2000 & Ton \\
\hline
\end{tabular}

The method used is the calculation according to the numerical approach assisted by computational software. The first calculation interval is planned with the slipway launch, and then the next one is planned with the airbags that have been implemented previously. The calculation results can be grouped in a table. The result was also drawn into a diagram for an easier read and technical analysis. The data provided includes the period of stern lift and economic steps and the cost of carrying out the ship launching in each type of launch. The launch weight calculation refers to the ship's steel weight when the ship is empty or often referred to as LWT (Leight Weight Tonnage). Assuming the launch weight is a combination of the empty ship's weight with the weight of the launch equipment. The Formula 1, 2 and 3 are used for determining launch weight.

$$
W p=L W T+(10 \% x L W T)
$$

Where $W p$ is the launch weight in tons, and $L W T$ is the shipping weight consisting of the weight of steel, the construction weight of the ship is in tons. Then to get the $P c$ price, the Launch Weight $(\mathrm{P})$ is multiplied by the distance from the center of gravity to the ramp's end.

$$
P c=P x c
$$

Pc's value is in (ton meter), while for $c$ is the distance from the center of gravity to the end of the land (meters), and $P$ is the tonne. The approach to the mathematical formula for the value of $c$ is:

$$
c=(s+h)-g
$$

The value of $c$ is the distance from the center of gravity to the end of the land (meters). $S$ is the length of the skating platform (meters), while $h$ is the distance from the tip of the ship to the last runway (meters), $g$ is the distance of the ship's center of gravity to the stern end of the ship (Tupper, 2013).

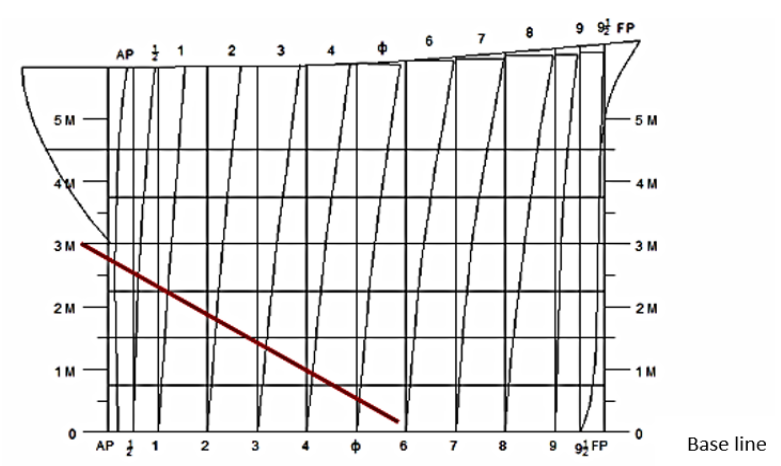

Figure 2. Bonjean curve measurement

Buoyancy is the main component used by the ship to exert a buoyant force opposite the gravitational force. It experiences a stern lift, which is lifting the stern when it enters the third period in a ship's launcher. This buoyancy $(Y V)$ is obtained by calculating the Simpson theory on the ship's Bonjean curve, which is in the submerged part of the ship (Tupper, 2013)]. Meanwhile, $d$ value is obtained from the distance of the floating-point to the end of the foundation. The buoyancy that occurs is a wide area of the ship's wet plane. Wet areas can be assumed to have an upward buoyancy. The way to calculate the Bonjean curve volume is to measure the diagonal line that intersects the ordinate line and the ship's area line, as can be seen Figure 2. The following is a representation of the YVd calculation.

The exact distance will depend on the ship's beam and the arrangement of the slipway structure. The designer shall be able to ensure that load can be transmitted safely between the base and hull of the ship through the launching shoe. Since the ship's shape greatly influenced the planning of the runway, the section of the skate closest to the bow and stern was probably quite high. The load held by them should be calculated carefully and maybe around $20 \%$ of the total weight. The skates are secured to a ship before launching. Therefore, grease can be inserted between the skates and the launch pad. This guard also holds the launch shoes as the ship moves down the runway, thus preventing them from falling and damaging the ship's underside. The skate is a wooden beam that is generally used as the hull base on the launch rail. The length of the skates $(S) 80 \%-90 \%$ of the length of the ship (Lpp) (Tupper, 2013)], Meanwhile, from the maximum pressure limit, the minimum width of the launching shoe can be found by using the Formula 4 approach.

$$
b=\frac{W p}{n \leqslant \sigma_{\max }}
$$




\section{TEKNIK, 41 (3), 2020, 228}

Where $b$ is the maximum acceptable width in meters, $W p$ is the launch weight (tonnes), $n$ is the number of skates planned, $S$ is the length of the launch pad (meters), and $\sigma_{\max }$ is the average maximum stress that can be accepted by the launch shoes (ton/m). On the other hand, the maximum height of the launching shoes are adjusted to the distance capacity of the people working under them (conditions in the field).

The airbag is a pneumatic balloon in a cylinder's shape with an extension containing synthetic wire like any other tire, as can be seen figure 3 . The combination of these components has the strength to withstand loads well to work in all conditions (dry or wet conditions). Ideally, airbags will distribute the stress due to the ship's load (Yu et al., 2015),14]. In the end, there is an end fitting.

The specifications of the airbags used were $0,8-2$ $\mathrm{m}$ for diameter (D), $6-18 \mathrm{~m}$ for effective length, and 7 $-19,5 \mathrm{~m}$ for total length.

\section{Results and Discussions}

Technical analysis can be started by calculating the weight of the ship using computer software, modeling the ship to determine the distance of the tank and the location of the tank ( $\mathrm{Yu}$ et al., 2015)]. From the model that has been made, we can analyze the

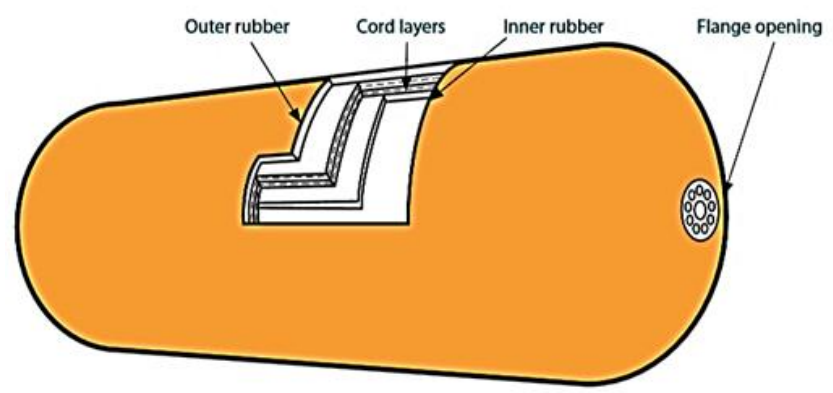

Figure 3. Airbag structure

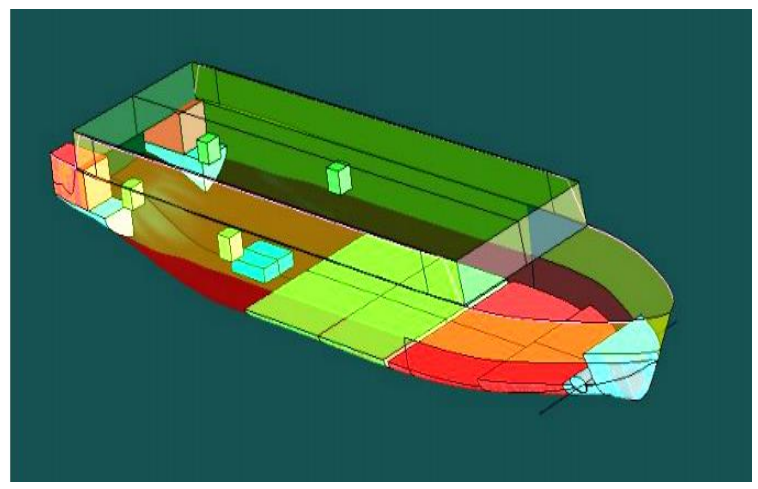

Figure 4. Model of the KM Sabuk Nusantara 72 Ship

doi: 10.14710/teknik.v41n3.33710 capacity for each tank on the ship, including if the ship is empty, see Figure 4.

After modeling the tank capacity and weight of the tank are calculated, if not with the tank, the weight of the ship is 976.9 tonnes. This is the weight of the empty vessel, including the construction weight and the shell steel plate. So that by using the launch calculation formula, results are obtained, see Table 2:

In calculating the launch with airbags, drawing was previously carried out with CAD (Computer Aided Design) to represent the scenario or condition of the ship when it was launched with airbags, see figure 5 . The number of airbags used in the launching process is 12 units, with each planned installation is $3-4$ meters away. This description can be used to calculate how much the ship's buoyancy $(y V d)$ is on the part of the ship immersed in water (shaded blue). It can also be used to measure the distance of the longitudinal center of gravity of the ship (LCG) to the end of the ship's runway, as well as the distance of buoyancy. Longitudinal/LCB (Longitudinal Center of Buoyancy) against the end of the runway. Using the Simpson formula approach, the following calculations are carried out, using slipway steps 5 to 6 from the measurement results of the Bonjean curve, the following data are obtained, see Table 3.

Table 2. The calculation results

\begin{tabular}{lcc}
\hline \multicolumn{1}{c}{ Planning } & Result & Unit \\
\hline $\mathrm{Wp}$ & 1074,59 & ton \\
$\mathrm{Pc}$ & 29800,33 & ton.m \\
$\mathrm{S}$ & 92,7 & $\mathrm{~m}$ \\
Launch shoes (15 units) & $38 \times 30 \times 32$ & $\mathrm{~cm}$ \\
The slope of the runway & $3,18^{0}$ & degrees \\
\hline
\end{tabular}

Table 3. The measurement result of the Bonjean curve

\begin{tabular}{cccccc}
\hline Station & Luas(A) & $\mathbf{s}$ & $\mathbf{A} \mathbf{x} \mathbf{~ s}$ & $\mathbf{N}$ & $\mathbf{A} \mathbf{x ~ s ~ x ~ N ~}$ \\
\hline $\mathrm{Ap}$ & 0.000 & 1 & 0.00 & 10 & 0.00 \\
1 & 0.413 & 4 & 1.65 & 9 & 14.87 \\
2 & 3.976 & 2 & 7.95 & 8 & 63.62 \\
3 & 6.742 & 4 & 26.97 & 7 & 188.78 \\
4 & 8.026 & 2 & 16.05 & 6 & 96.31 \\
5 & 7.904 & 4 & 31.62 & 5 & 158.08 \\
6 & 6.695 & 2 & 13.39 & 4 & 53.56 \\
7 & 5.276 & 4 & 21.10 & 3 & 63.31 \\
8 & 3.652 & 2 & 7.30 & 2 & 14.61 \\
9 & 1.831 & 4 & 7.32 & 1 & 7.32 \\
10 & 0.000 & 1 & 0.00 & 0 & 0.00 \\
& & $\mathrm{~S}_{1}=$ & 133.36 & $\mathrm{~S}_{2}=$ & 660.46 \\
\hline
\end{tabular}

Dislacement $=1 / 3 \times \mathrm{d} \times \mathrm{SS} 1$

$\begin{aligned} \mathrm{LCB} & =140.030 \mathrm{~m}^{3} \\ & =15.600 \mathrm{~m}\end{aligned}$ 


\section{TEKNIK, 41 (3), 2020, 229}

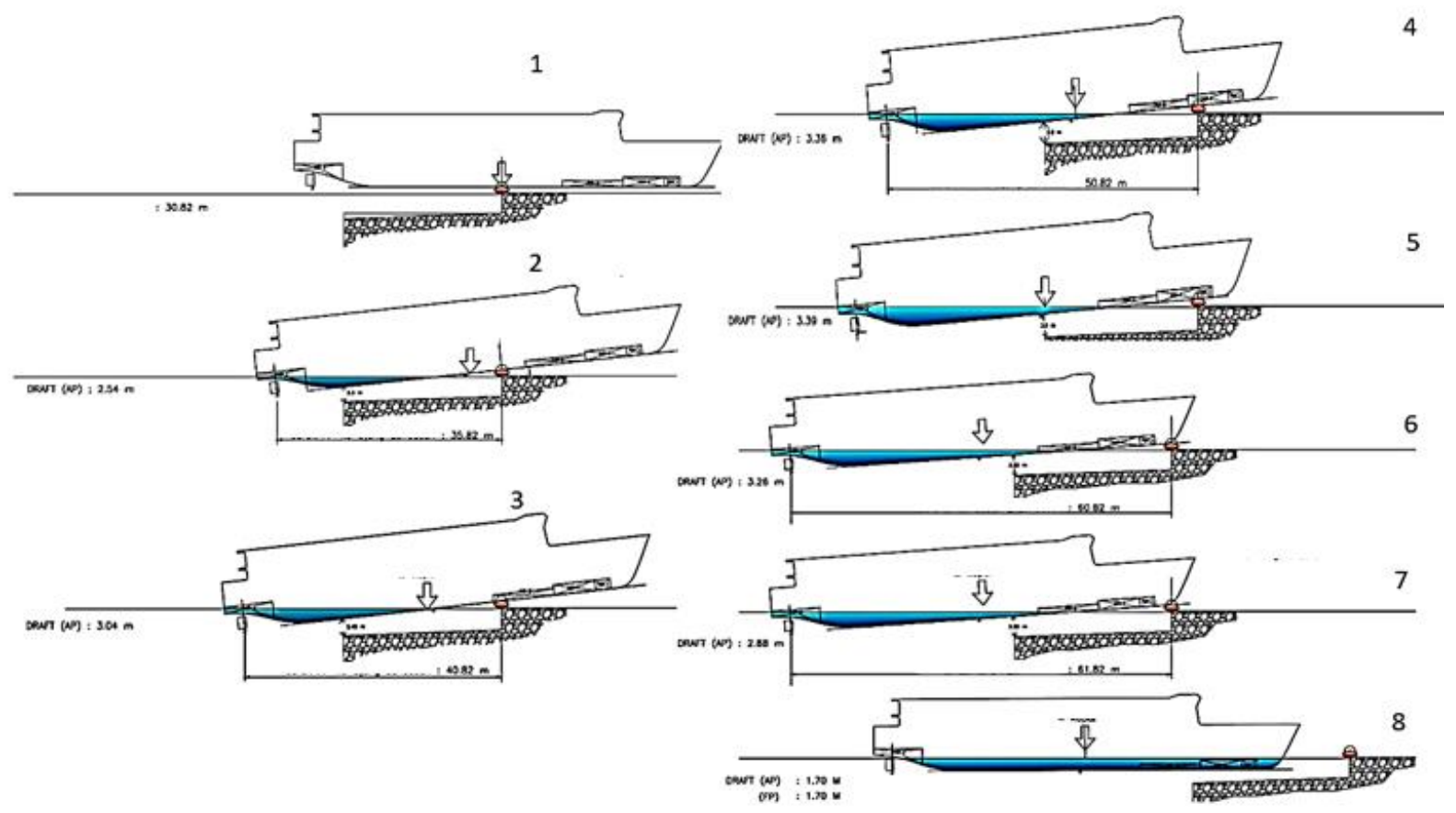

Figure 5. Schematic of the ship launching process with airbags

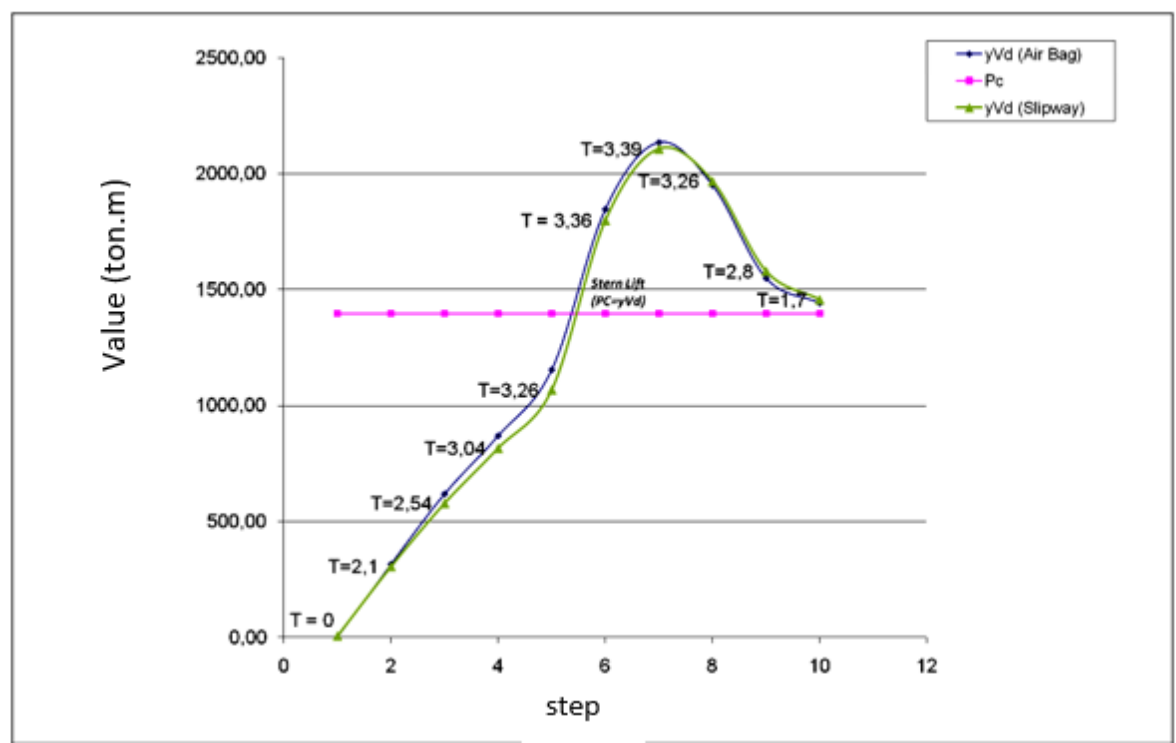

Figure 6. Comparison of Stern lift Charts Slipway and airbag launches

So that $y \mathrm{Vd}$ is the multiplication between the displacement and the distance of the buoyancy points in that step, the value is 1396.97 ton.m. The calculation is also carried out on the airbag launching method to obtain the same displacement value. However, the time for the ship to experience a stern lift is faster.

Mathematical calculations using the software result in a comparison of the launch diagram. It showed that the stern lift step or the start of the stern lifting because the amount of buoyancy on the ship is faster on the airbag than the slipway, see Figure 6. The graph showed that the buoyancy condition of each loaded vessel that is immersed in the water. There is a significant value increase in steps 5 to 6 . Both the slipway and the airbag experience a stern lift condition with a value of 1396.97 ton.m. When submerged in water, the maximum value of the vessel is 3.39 meters, where the maximum value of buoyancy is 2107.20 tons. 


\section{TEKNIK, 41 (3), 2020, 230}

Furthermore, in steps 8 to 10, both ways of gradually decreasing the buoyancy force, which is 300 ton.m, to the last laden condition of the ship, which is 1.7 meters with a buoyancy of 1456.88 tonnes.

Economic analysis can be calculated based on the amount of cost required to plan this launch based on surveys and data collection at the shipyard ( $\mathrm{Yu}$ et al., 2015)]. From the cost comparison, it can be seen that 3 parameters are used as references in this economic analysis. See Table 4.

From these results, it can be ascertained that each selection of the launching method has advantages and disadvantages in terms of investment costs and people working hours. So that in planning a ship launching method, it is necessary to consider from the point of view of technical studies which affect the costs incurred. As seen in the hours of people using airbags, there is a decrease in working hours by $44 \%$ when compared to launching using a slipway. This also happened to work productivity, where it was $84 \%$ more time effective. So it can be said that the two scopes have increased the level of effectiveness, which is quite significant. It is different when viewed from an investment point of view in the launching of the use of the slipway. It is more economical than the airbag. The difference is $43 \%$ more economical using the slipway.

\section{Conclusion}

Ship launching is a part that needs to be considered in the ship production process. This comparison with numerical calculations is one of the shipbuilding industry considerations in determining the launch plan for the ships it produces. In this case, the calculation results show that both the slipway or the airbags experience a stern lift almost simultaneously, only for the airbags. It is faster due to the airbag structure's nature containing air and being an additional buoyancy of the ship. On the other hand, the placement and arrangement of airbags are of particular concern to keep the ship in a vertical position and not experience rolling during the launching process. The graph of the calculation results shows that the ship experiences a buoyant force after obtaining a submerged part of the hull. Therefore, there is a part where the maximum area

Table 4. Cost comparison

\begin{tabular}{clccc}
\hline No & Calculation & $\begin{array}{c}\text { Slipway } \\
\text { (1 set) }\end{array}$ & $\begin{array}{c}\text { Airbag } \\
(\mathbf{1 2} \text { units) }\end{array}$ & $\begin{array}{c}\text { Informa } \\
\text { tion }\end{array}$ \\
\hline 1 & Hours of People & 86,4 & 48 & Per Week \\
\hline 2 & $\begin{array}{l}\text { Investment/Rental } \\
\text { Costs }\end{array}$ & $\begin{array}{c}\text { IDR. } \\
40.000 .000\end{array}$ & $\begin{array}{c}\text { IDR. } \\
70.000 .000\end{array}$ & $\begin{array}{c}\text { One } \\
\text { Activity }\end{array}$ \\
\hline 3 & $\begin{array}{l}\text { Work } \\
\text { productivity }\end{array}$ & 45 & 7 & Hour \\
\hline
\end{tabular}

of buoyancy then decreases along with the ship-laden condition, which becomes a keel event.

Both launch types can be applied by looking at the economic side and each shipyard's ability to carry out the launching process and see its main size. If it applies to slipway launches, the initial investment will be more significant. However, along with the increase in ship production, this will soon be covered more precisely in large-class shipyards with advanced technology and sufficient outside areas. Suppose this is applied to the launch of airbags. In that case, the initial investment costs will be smaller with a small production capacity, meaning that it will be appropriate for small and medium-class shipyards.

\section{References}

Dek, C., Overkamp, J.-L., Toeter, A., Hoppenbrouwer, T., Slimmens, J., van Zijl, J., Areso Rossi, P., Machado, R., Hereijgers, S., Kilic, V., \& Naeije, M. (2020). A recovery system for the key components of the first stage of a heavy launch vehicle. Aerospace Science and Technology, 100, 105778. https://doi.org/10.1016/j.ast.2020.105778

Fitriadhy, A., \& Malek, A. M. A. (2017). Computational fluid dynamics analysis of a ship's side launching in restricted waters. Journal of Mechanical Engineering and Sciences, 11, 2993-3003. https://doi.org/10.15282/jmes.11.4.2017.3.0269

He, H., Chen, Z., He, C., Ni, L., \& Chen, G. (2015). A hierarchical updating method for finite element model of airbag buffer system under landing impact. Chinese Journal of Aeronautics, 28(6), 1629-1639.

https://doi.org/10.1016/j.cja.2015.10.010

Ianagui, A. S. S., \& Tannuri, E. A. (2015). Cooperative Sliding Mode Control Applied To A Fleet Of DP Vessels. IFAC-PapersOnLine, 48(16), 299-304. https://doi.org/10.1016/j.ifacol.2015.10.296

Irawanto, Z., Puryantini, N., Ali, B., \& Prasodjo, B. (2019). Kajian eksperimental peluncuran kapal menggunakan air bag. Majalah Ilmiah Pengkajian Industri, $13, \quad 55$. https://doi.org/10.29122/mipi.v13i1.3243

Mann, B. Q., Maggs, J. Q., Khumalo, M. C., Khumalo, D., Parak, O., Wood, J., \& Bachoo, S. (2015). The KwaZulu-Natal Boat Launch Site Monitoring System: A novel approach for improved management of small vessels in the coastal zone. Ocean \& Coastal Management, 104, 57-64. https://doi.org/10.1016/j.ocecoaman.2014.12.003 


\section{TEKNIK, 41 (3), 2020, 231}

Senjanović, I., Katavić, J., Vukčević, V., Vladimir, N., \& Jasak, H. (2020). Launching of ships from horizontal berth by tipping tables - CFD simulation of wave generation. Engineering Structures, $\quad 210, \quad 110343$. https://doi.org/10.1016/j.engstruct.2020.110343

Song, Z., Xie, Z., Qiu, L., Xiang, D., \& Li, J. (2020). Prospects of sea launches for Chinese cryogenic liquid-fueled medium-lift launch vehicles. Chinese Journal of Aeronautics. https://doi.org/10.1016/j.cja.2020.06.018

Thomas, B., Hadfield, M., \& Austen, S. (2009). Experimental wear modelling of lifeboat slipway launches. Tribology International, 42(11), 17061714.

https://doi.org/10.1016/j.triboint.2009.04.043

Tupper, E. (2013). Introduction to Naval Architecture. $7^{\text {th }}$ ed. Oxford, UK: Butterworth-Heinemann.

Xiao, Q., Zhou, W., \& Zhu, R. (2020). Effects of wavefield nonlinearity on motions of ship advancing in irregular waves using HOS method. Ocean Engineering, $199, \quad 106947$. https://doi.org/10.1016/j.oceaneng.2020.106947

Yamagami, T., Iijima, I., Izutsu, N., Kawasaki, T., Matsuzaka, Y., Namiki, M., Saito, Y., Seo, M., Toriumi, M., Tanaka, S., \& Matsushima, K. (2006). Launching of a 500,000 cubic meter balloon with the semi-dynamic launching method. Advances in Space Research, 37(11), 2033-2037.

https://doi.org/10.1016/j.asr.2006.01.011

Ye, Z. (1994). Dynamics of ships side launching. Computers \& Structures, 53(4), 861-865. https://doi.org/10.1016/0045-7949(94)90374-3

Yu, L., Li, Y., Xia, L., Ding, J., \& Yang, Q. (2015). Research on mechanics of ship-launching airbags I-Material constitutive relations by numerical and experimental approaches. Applied Ocean Research, 52 , 222-233. 